\title{
焙烧温度对锂离子电池正极材料 $\mathrm{Li}_{2} \mathrm{MnSiO}_{4} / \mathrm{C}$ 电化学性能的影响
}

\author{
魏 怡 ${ }^{1, *}$ 王利娟 $^{1}$ 问继 ${ }^{1}$ 沙 鸥 $^{1}$ 唐致远 ${ }^{1}$ 马 莉 $^{2}$ \\ ('天津大学化工学院, 天津 300072 ; ${ }^{2}$ 东莞迈科科技有限公司, 广东东莞 523800 )
}

\begin{abstract}
摘要: 采用液相法合成了 $\mathrm{Li}_{2} \mathrm{MnSiO}_{4} / \mathrm{C}$ 复合正极材料, 并研究了不同焙烧温度对材料的结构、形貌和电化学性 能的影响. 利用热重(TG)分析了材料前驱体的热行为, 确定了合成 $\mathrm{Li}_{2} \mathrm{MnSiO}_{4} / \mathrm{C}$ 复合正极材料的焙烧温度范围 为 600-800 ${ }^{\circ} \mathrm{C} . \mathrm{X}$ 射线衍射 (XRD) 测试结果表明, 不同温度下合成的样品材料均具有正交结构, 且空间群为 $P m n 2_{1}$, 同时利用扫描电子显微镜 (SEM) 对所得样品材料的微观形貌及颗粒大小进行了表征. 将所得 $\mathrm{Li}_{2} \mathrm{MnSiO}_{4} / \mathrm{C}$ 复合正极材料组装成扣式电池, 并在不同的电流密度下进行充放电测试, 结果表明: $700{ }^{\circ} \mathrm{C}$ 合成 的样品材料电化学性能最佳, 具有较高的库仑效率及很好的循环稳定性.
\end{abstract}

关键词：锂离子电池； 正极材料； $\mathrm{Li}_{2} \mathrm{MnSiO}_{4}$ ； 液相法；焙烧温度

中图分类号： O646; TM912.9

\section{Calcination Temperature Effects on the Electrochemical Performance of $\mathrm{Li}_{2} \mathrm{MnSiO}_{4} / \mathrm{C}$ Cathode Material for Lithium Ion Batteries}

\author{
WEI Yi ${ }^{1, *} \quad$ WANG Li-Juan ${ }^{1} \quad$ YAN Ji ${ }^{1} \quad$ SHA Ou ${ }^{1} \quad$ TANG Zhi-Yuan ${ }^{1} \quad$ MA Li $^{2}$ \\ ( ${ }^{1}$ School of Chemical Engineering and Technology, Tianjin University, Tianjin 300072, P. R. China; \\ ${ }^{2}$ McNair Technology Company, Limited, Dongguan 523800, Guangdong Province, P. R. China)
}

\begin{abstract}
As a new potential cathode material for lithium ion batteries, $\mathrm{Li}_{2} \mathrm{MnSiO}_{4} / \mathrm{C}$ was synthesized by a solution method. The thermal behavior of the precursor for $\mathrm{Li}_{2} \mathrm{MnSiO}_{4} / \mathrm{C}$ was measured by thermogravimetric (TG) analysis and the range of calcination temperatures from 600 to $800{ }^{\circ} \mathrm{C}$ was determined. X-ray powder diffraction (XRD) patterns indicated that all the $\mathrm{Li}_{2} \mathrm{MnSiO}_{4} / \mathrm{C}$ samples crystallized in an orthorhombic structure with space group Pmn2. The morphology and particle size of the samples were also characterized by scanning electron microscopy (SEM). The effects of calcination temperature on the electrochemical performance of $\mathrm{Li}_{2} \mathrm{MnSiO}_{4} / \mathrm{C}$ were studied using galvanostatic charge-discharge measurements at various current densities. The results showed that the sample prepared at $700{ }^{\circ} \mathrm{C}$ exhibited a much higher coulombic efficiency and better cyclic performance than the other samples.
\end{abstract}

Key Words: Lithium ion battery; Cathode material; $\mathrm{Li}_{2} \mathrm{MnSiO}_{4}$; Solution method; Calcination temperature

\section{Introduction}

Large scale lithium ion batteries have been widely used in telecommunication, portable computers, and entertainment devices, due to their advantages of high energy density and environmental friendliness. However, since the increasingly further higher energy and power density demands brought by $3 \mathrm{G}$ elec- tronic devices and electric vehicles, searching for a new generation of cathode materials for lithium ion batteries has been an urgent mission toward researchers. Since $\mathrm{LiFePO}_{4}$ cathode material was discovered by Goodenough group, ${ }^{1}$ many pursuers have focused on the polyanion-based cathode materials $\mathrm{Li}_{y} \mathrm{MXO}_{4}$ $(\mathrm{M}=\mathrm{Fe}, \mathrm{Mn}, \mathrm{Co}, \mathrm{Ni} ; \mathrm{X}=\mathrm{P}, \mathrm{Si}, \mathrm{Ge} ; y=1,2)$. These materials pos-

Received: July 4, 2011; Revised: September 6, 2011; Published on Web: September 13, 2011.

"Corresponding author. Email: weiyi_777@163.com; Tel: +86-769-83017180; Fax: +86-769-83195372.

The project was supported by the National Natural Science Foundation of China (20973124).

国家自然科学基金(20973124)资助项目

(C) Editorial office of Acta Physico-Chimica Sinica 
sess $\mathrm{M}-\mathrm{O}-\mathrm{X}$ bonds, ${ }^{2,3}$ the selection of $\mathrm{X}$ elements can change the polarization of $\mathrm{X}-\mathrm{O}$ and $\mathrm{M}-\mathrm{O}$ bonds, which will give rise to different inductive effects. ${ }^{4}$ In other words, the electronegativity of $\mathrm{X}$ elements determines the iono-covalent character of $\mathrm{M}-\mathrm{O}$ bonds and hence the electrochemical performance of $\mathrm{Li}_{y} \mathrm{MXO}_{4}$ cathode materials.

Recently, polyanion orthosilicate family $\mathrm{Li}_{2} \mathrm{MSiO}_{4}(\mathrm{M}=\mathrm{Fe}$, $\mathrm{Mn}, \mathrm{Co}, \mathrm{Ni}$ ) has fascinated many researchers because its strong $\mathrm{Si}-\mathrm{O}$ bonds can stabilize the lattice structure like the $\mathrm{P}-\mathrm{O}$ bonds in $\mathrm{LiFePO}_{4}{ }^{5}$ And the $\mathrm{M}^{2+} / \mathrm{M}^{3+}$ and $\mathrm{M}^{3+} / \mathrm{M}^{4+}$ redox couples in $\mathrm{Li}_{2} \mathrm{MSiO}_{4}$ make it possible to exchange two electrons in electrochemical reaction, corresponding to a theoretical capacity more than $330 \mathrm{mAh} \cdot \mathrm{g}^{-1}$.

Since first being proposed by Nytén et al. ${ }^{6}$ in 2005, cathode material $\mathrm{Li}_{2} \mathrm{FeSiO}_{4}$ has gradually entered people's horizons. However, many researchers have encountered numerous obstacles. During the charge/discharge process, only $1 \mathrm{~mol}$ lithium ion is exchanged from a $\mathrm{Li}_{2} \mathrm{FeSiO}_{4}$ unit based on the reaction: ${ }^{7}$ $\mathrm{Li}_{2} \mathrm{FeSiO}_{4} \rightarrow \mathrm{LiFeSiO}_{4}+\mathrm{Li}^{+}+\mathrm{e}^{-}$, and the practical capacity is limited to be only $166 \mathrm{mAh} \cdot \mathrm{g}^{-1}$, much lower than the theoretical capacity $\left(332 \mathrm{mAh} \cdot \mathrm{g}^{-1}\right){ }^{8}$ In addition, the working voltage of $\mathrm{Li}_{2} \mathrm{FeSiO}_{4}$ material is as low as $2.8 \mathrm{~V}^{9,10}$ so it cannot meet the further demands of high power density. Compared with $\mathrm{Li}_{2} \mathrm{FeSiO}_{4}, \mathrm{Li}_{2} \mathrm{MnSiO}_{4}$ has two higher charge voltage plateaus at 4.1 and $4.5 \mathrm{~V}$ for the extraction of two lithium ions, ${ }^{11}$ and the capacity can reach $333 \mathrm{mAh} \cdot \mathrm{g}^{-1} \cdot{ }^{12}$ Therefore, $\mathrm{Li}_{2} \mathrm{MnSiO}_{4}$ cathode material has became the promising cathode material for lithium ion batteries.

There are many reports about the synthesis methods and electrochemical performance of $\mathrm{Li}_{2} \mathrm{MnSiO}_{4}$ cathode material. ${ }^{11-18}$ Liu et al. ${ }^{13}$ synthesized $\mathrm{Li}_{2} \mathrm{MnSiO}_{4}$ by a traditional solid-state reaction method, nevertheless, the specific capacity decayed severely from 256 to $3.2 \mathrm{mAh} \cdot \mathrm{g}^{-1}$ after 10 cycles. A modified Pechini sol-gel method was also employed to prepare $\mathrm{Li}_{2} \mathrm{MnSiO}_{4}$ by Dominko group, ${ }^{14-16}$ unfortunately, they only investigated the structure and basic electrochemical performance of $\mathrm{Li}_{2} \mathrm{MnSiO}_{4}$, without mentioning the improvement in its electron conductivity and cyclic performance. Yang ${ }^{11}$ and Aravindan ${ }^{17}$ et al. have studied the effects of synthesis conditions on the electrochemical performance of $\mathrm{Li}_{2} \mathrm{MnSiO}_{4}$ composites prepared by a solution route and a sol-gel route, respectively. However, both experiments were conducted at low current density, and the rate performance was not clarified.

Herein, a combination of X-ray powder diffraction (XRD), scanning electron microscrope (SEM), and galvanostatic charge-discharge measurements were utilized to investigate the effects of calcination temperature on the electrochemical performance of $\mathrm{Li}_{2} \mathrm{MnSiO}_{4} / \mathrm{C}$ composites prepared by a solution route. And, more meaningfully, their rate performance was also reported for the first time in detail.

\section{Experimental}

\subsection{Synthesis of $\mathrm{Li}_{2} \mathrm{MnSiO}_{4} / \mathrm{C}$}

$\mathrm{Li}_{2} \mathrm{MnSiO}_{4} / \mathrm{C}$ composites were synthesized via a solution route. Stoichiometric amounts of $\mathrm{CH}_{3} \mathrm{COOLi} \cdot 2 \mathrm{H}_{2} \mathrm{O}(99 \%)$, $\mathrm{Mn}\left(\mathrm{CH}_{3} \mathrm{COO}\right)_{2} \cdot 4 \mathrm{H}_{2} \mathrm{O}(99 \%)$ as raw materials were first dissolved in distilled water. The mixture of citric acid $\left(\mathrm{C}_{6} \mathrm{H}_{8} \mathrm{O}_{7} \cdot \mathrm{H}_{2} \mathrm{O}\right.$, $99 \%)$ and ethylene glycol $\left(\mathrm{C}_{2} \mathrm{H}_{6} \mathrm{O}_{2}, 99 \%\right)$ in a molar ratio of 1 : 2 , used as chelate agent and carbon source, was added into the solution under magnetic stirring. Subsequently, the saturated $\mathrm{Si}\left(\mathrm{CH}_{3} \mathrm{COO}\right)_{4}(99 \%)$ ethanol solution, was added. The mixture was transferred into reflux system at $80{ }^{\circ} \mathrm{C}$ for $24 \mathrm{~h}$ and followed evaporated at $75^{\circ} \mathrm{C}$ to enable the formation of gel. Then, the obtained gel was dried at $60{ }^{\circ} \mathrm{C}$ for at least $12 \mathrm{~h}$ in a vacuum oven, and preheated at $350{ }^{\circ} \mathrm{C}$ for $4 \mathrm{~h}$ to release residual vapour. After being ground and pressed into pieces, the preheated products were annealed under 600,700 , and $800{ }^{\circ} \mathrm{C}$ for $12 \mathrm{~h}$ in $\mathrm{N}_{2}$ atmosphere and marked as samples A, B, and C, respectively.

\subsection{Measurements}

Thermogravimetric (TG) (STARe system, METTLER-TOLEDO, Switzerland) analysis was employed to investigate the thermo behavior of the precursor for $\mathrm{Li}_{2} \mathrm{MnSiO}_{4} / \mathrm{C}$ sample from 30 to $800{ }^{\circ} \mathrm{C}$ at a heating rate of $10{ }^{\circ} \mathrm{C} \cdot \mathrm{min}^{-1}$ in $\mathrm{N}_{2}$ atmosphere.

The structure of $\mathrm{Li}_{2} \mathrm{MnSiO}_{4} / \mathrm{C}$ composites was measured by XRD (PTR Ш, Rigaku Corporation, Japan) using $\mathrm{Cu} K_{\alpha}$ radiation at ambient temperature, ranging from $3^{\circ}$ to $90^{\circ}$. SEM (JEOL-JSM-6380LA, JEOL Ltd., Japan) were utilized to observe the surface morphology of the samples.

In order to evaluate the carbon content coated on the $\mathrm{Li}_{2} \mathrm{MnSiO}_{4} / \mathrm{C}$ samples, a methodology of residual carbon content measurement was introduced. The $\mathrm{Li}_{2} \mathrm{MnSiO}_{4} / \mathrm{C}$ samples prepared at various temperatures were heated at $500{ }^{\circ} \mathrm{C}$ in air for $4 \mathrm{~h}$ to burn off the residual carbon. As there was simultaneous mass gained from the oxidation of $\mathrm{Mn}^{2+}$ ion to higher valence, as well as the loss due to the carbon removement, the pure $\mathrm{Li}_{2} \mathrm{MnSiO}_{4}$ samples without carbon-coated prepared at corresponding temperature were required. The mass changes $(\Delta m)$ consist of two parts, one is the reduction by gasification of carbon $\left(m_{\mathrm{C}}\right)$, and the other is the increase by the oxidation of $\mathrm{Li}_{2} \mathrm{MnSiO}_{4}\left(m_{\mathrm{L}}\right)$. So the residual carbon content can be calculated as follows:

$$
\Delta m=m_{\mathrm{L}}-m_{\mathrm{C}}
$$

$$
x=\left(\Delta m / m_{\mathrm{C} 1}\right)-\left(m_{\mathrm{L}} / m_{\mathrm{P} 1}\right)
$$

where, $x$ is the carbon content $(\%), m_{\mathrm{C} 1}$ and $m_{\mathrm{P} 1}$ are the initial masses of $\mathrm{Li}_{2} \mathrm{MnSiO}_{4} / \mathrm{C}$ sample and the corresponding pure $\mathrm{Li}_{2} \mathrm{MnSiO}_{4}$ sample for the test, respectively.

Electrochemical tests were performed using CR 2032 coin type cell. The cathode electrode was manufactured by mixing $\mathrm{Li}_{2} \mathrm{MnSiO}_{4} / \mathrm{C}$ sample, acetylene black, and polytetrafluoroethylene (PTFE) with a mass ratio of 80:10:10. The mixture was dissolved in ethyl alcohol and dispersed through ultrasonic for 1 h. After evaporating ethyl alcohol, the cathode electrode was obtained by pressing a piece with a diameter of $8 \mathrm{~mm}$ on an aluminum foil with a diameter of $10 \mathrm{~mm}$ under a certain pres- 
sure, and then dried in a vacuum oven at $120^{\circ} \mathrm{C}$ for $12 \mathrm{~h}$. The coin-type cells were assembled in an argon-filled glove box, using lithium metal foil as negative electrode, Celgard 2300 membrane as the separator, and $1 \mathrm{~mol} \cdot \mathrm{L}^{-1} \mathrm{LiPF}_{6}$ in a mixture of ethylene carbonate (EC) and dimethyl carbonate (DMC) (provided by TianCi, Guangzhou, China) as the electrolyte. Galvanostatic charge-discharge measurements (LX-PCBT-13832D, Lixing, Wuhan, China) were performed in a potential range of 1.5-4.8 V (vs $\left.\mathrm{Li} / \mathrm{Li}^{+}\right)$at various current densities.

\section{Results and discussion}

Fig.1 exhibits the TG and DSC plots of the precursor of $\mathrm{Li}_{2} \mathrm{MnSiO}_{4} / \mathrm{C}$ in $\mathrm{N}_{2}$ atmosphere. As the three sharp peaks shown in the DSC curve, the mass loss can be divided into three regions. The first region is observed in the range of $50-140{ }^{\circ} \mathrm{C}$ due to the evaporation of physical water. The second region in the range of $260-350{ }^{\circ} \mathrm{C}$ is attributed to the dehydration of crystal water and the decomposition of carbonate. A slow decrease of the mass after $550{ }^{\circ} \mathrm{C}$ in the last region may be caused by the crystalline formation of $\mathrm{Li}_{2} \mathrm{MnSiO}_{4} / \mathrm{C}$. Based on the result of TG analysis, the optimal calcination temperature from 600 to $800{ }^{\circ} \mathrm{C}$ with the interval of $100{ }^{\circ} \mathrm{C}$ was determined.

Based on Eq.(2), the amount of carbon in the $\mathrm{Li}_{2} \mathrm{MnSiO}_{4} / \mathrm{C}$ samples $\mathrm{A}, \mathrm{B}$, and $\mathrm{C}$ are $6.57 \%, 4.81 \%$, and $1.13 \%$, respectively. As the increasing of calcination temperature, the carbon content in the sample is reduced.

The powder X-ray diffraction patterns of $\mathrm{Li}_{2} \mathrm{MnSiO}_{4} / \mathrm{C}$ samples synthesized under various calcination temperatures are shown in Fig.2. The sharp intense peaks presented around $2 \theta=$ $16.498^{\circ}, 24.420^{\circ}, 28.298^{\circ}, 33.147^{\circ}, 36.158^{\circ}$ are indexed as the (010), (011), (111), (210), (002) planes, which can be assigned to $\mathrm{Li}_{2} \mathrm{MnSiO}_{4} / \mathrm{C}$ phase with the orthorhombic unit in space group $P m n 2_{1}$. However, the pure phase $\mathrm{Li}_{2} \mathrm{MnSiO}_{4} / \mathrm{C}$ sample is not obtained in the present conditions, which may result in the low capacity and unstable structure of $\mathrm{Li}_{2} \mathrm{MnSiO}_{4} / \mathrm{C}$ composites, corresponding with the other reports. ${ }^{7,11-17}$ Impurities, such as $\mathrm{MnO}$ and $\mathrm{Li}_{2} \mathrm{SiO}_{3}$, are detected in the three samples as shown in Fig.2, and $\mathrm{Mn}_{2} \mathrm{SiO}_{4}$ only exits in $\mathrm{Li}_{2} \mathrm{MnSiO}_{4} / \mathrm{C}$ (sample $\mathrm{C}$ ). Besides, there are also some unknown peaks in the pattern of $\mathrm{Li}_{2} \mathrm{MnSiO}_{4} / \mathrm{C}$ (sample A). While low level impurities are discovered in $\mathrm{Li}_{2} \mathrm{MnSiO}_{4} / \mathrm{C}$ (sample B). Therefore, $\mathrm{Li}_{2} \mathrm{MnSiO}_{4} /$

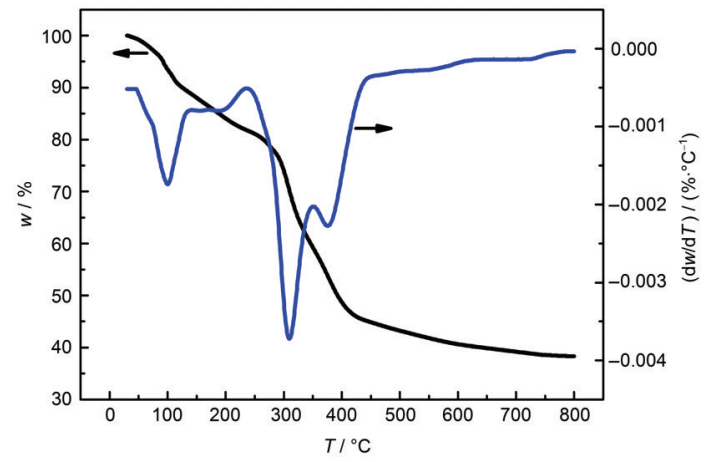

Fig.1 TG and DSC curves of precursor for $\mathrm{Li}_{2} \mathrm{MnSiO}_{4} / \mathrm{C}$ from 30 to $800{ }^{\circ} \mathrm{C}$

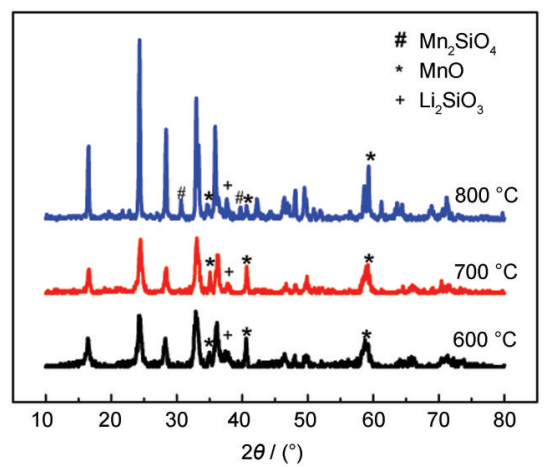

Fig.2 XRD patterns of the $\mathrm{Li}_{2} \mathrm{MnSiO}_{4} / \mathrm{C}$ samples at various temperatures

$\mathrm{C}$ (sample B) is identified as the purest phase.

Fig. 3 shows the SEM images of $\mathrm{Li}_{2} \mathrm{MnSiO}_{4} / \mathrm{C}$ samples under different calcination temperatures. As shown in Fig.3(b), the particle size of $\mathrm{Li}_{2} \mathrm{MnSiO}_{4} / \mathrm{C}$ (sample $\mathrm{B}$ ) ranges from 0.2 to 1.0 $\mu \mathrm{m}$, with $0.5 \mu \mathrm{m}$ on average. While for $\mathrm{Li}_{2} \mathrm{MnSiO}_{4} / \mathrm{C}$ (sample A and sample C), the average sizes are 0.7 and $1.0 \mu \mathrm{m}$ (Fig.3 $(\mathrm{a}, \mathrm{c}))$, respectively. In theory, the particle size will grow with the increasing of calcination temperature because of the crystal growth, and thus the particle size of $\mathrm{Li}_{2} \mathrm{MnSiO}_{4} / \mathrm{C}$ (sample $\mathrm{C}$ ) is larger than the others. However, the particle size obtained for $\mathrm{Li}_{2} \mathrm{MnSiO}_{4} / \mathrm{C}$ (sample A) is still larger than the $\mathrm{Li}_{2} \mathrm{MnSiO}_{4} /$ $\mathrm{C}$ (sample B), which may be ascribed to the higher coated-carbon content. ${ }^{19}$ Although the presence of carbon can prevent the crystal growth, the higher carbon content will still lead to the agglomeration of the small particles. That is due to the forma-
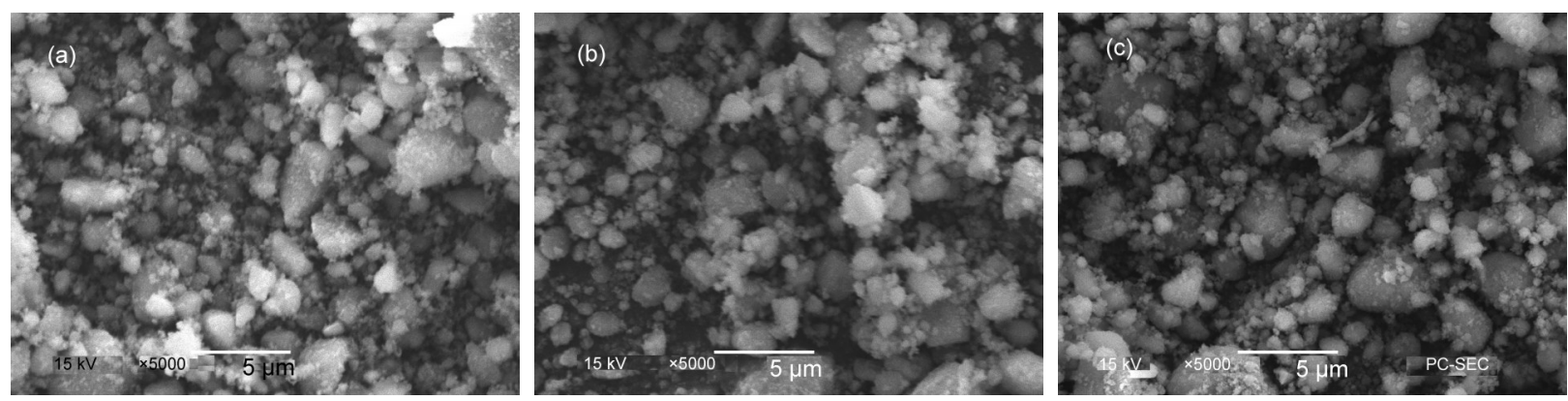

Fig.3 SEM images of $\mathrm{Li}_{2} \mathrm{MnSiO}_{4} / \mathrm{C}$ prepared at different calcination temperatures (a) $600{ }^{\circ} \mathrm{C}$, (b) $700{ }^{\circ} \mathrm{C}$, (c) $800^{\circ} \mathrm{C}$ 
tion of network which consists of carbon-coated $\mathrm{Li}_{2} \mathrm{MnSiO}_{4} / \mathrm{C}$ particles. The decomposition of citric acid and ethylene glycolas during the synthesis process may coat a thick carbon-layer on the surface of $\mathrm{Li}_{2} \mathrm{MnSiO}_{4}$ particle, and then form a network to make good connection of the particles. ${ }^{20}$ In contrast, the uniform particles are obtained for $\mathrm{Li}_{2} \mathrm{MnSiO}_{4} / \mathrm{C}$ (sample $\mathrm{B})$, and the agglomerated bulks are almost unobserved. Thus, $\mathrm{Li}_{2} \mathrm{MnSiO}_{4} / \mathrm{C}$ (sample B) may exhibit the best electrochemical performance among the three samples, which will be discussed in the following sections.

The initial charge-discharge curves of $\mathrm{Li}_{2} \mathrm{MnSiO}_{4} / \mathrm{C}$ samples under different calcination temperatures at various current densities are exhibited in Fig.4. It is noted that all the samples present a certain degree of irreversible capacity. The specific capacity of $\mathrm{Li}_{2} \mathrm{MnSiO}_{4} / \mathrm{C}$ (sample $\mathrm{A}$ ) is slightly lower than that of $\mathrm{Li}_{2} \mathrm{MnSiO}_{4} / \mathrm{C}$ (sample $\mathrm{B}$ ), but a significant difference can be observed between the two samples with the current densities increasing to 10 and $20 \mathrm{~mA} \cdot \mathrm{g}^{-1}$ (in Fig.4(b) and Fig.4(c)). For $\mathrm{Li}_{2} \mathrm{MnSiO}_{4} / \mathrm{C}$ (sample B) in Fig.4, the initial discharge capacity can reach $187.12,169.49$, and $147.89 \mathrm{mAh} \cdot \mathrm{g}^{-1}$ at the current densities of 5,10 , and $20 \mathrm{~mA} \cdot \mathrm{g}^{-1}$, respectively, while $\mathrm{Li}_{2} \mathrm{MnSiO}_{4} / \mathrm{C}$ (sample $\mathrm{C}$ ) exhibits a poor initial specific capacity at each current density. Additionally, only $\mathrm{Li}_{2} \mathrm{MnSiO}_{4} / \mathrm{C}$ (sample B) exhibits two voltage plateaus at 4.1 and $4.5 \mathrm{~V}$. It is well known that phase purity and particle size have important effects on the electrochemical performance. ${ }^{21}$ From the results of XRD and $\mathrm{SEM}, \mathrm{Li}_{2} \mathrm{MnSiO}_{4} / \mathrm{C}$ (sample B) presents lower level impurities and more uniform particle size. This means that the side reactions caused by impurities are well restrained by the optimal calcination temperature, and meanwhile, the specific surface area is increased due to the uniform and small parti- cle size. Consequently, a higher capacity and visible voltage plateaus of $\mathrm{Li}_{2} \mathrm{MnSiO}_{4} / \mathrm{C}$ are obtained even at a high current density of $20 \mathrm{~mA} \cdot \mathrm{g}^{-1}$.

Fig. 5 shows the cyclic performance of $\mathrm{Li}_{2} \mathrm{MnSiO}_{4} / \mathrm{C}$ samples under different calcination temperatures at various current densities. Although all samples present an irreversible capacity loss, the capacity retentions of $\mathrm{Li}_{2} \mathrm{MnSiO}_{4} / \mathrm{C}$ (sample B) still maintain $34.90 \%, 57.01 \%$, and $58.29 \%$ in the 10 th cycle at various current densities of 5,10 , and $20 \mathrm{~mA} \cdot \mathrm{g}^{-1}$, respectively. However, for $\mathrm{Li}_{2} \mathrm{MnSiO}_{4} / \mathrm{C}$ (sample A), it only shows $17.66 \%$, $26.11 \%$, and $29.45 \%$ at corresponding current densities, respectively. At each current density, the capacity of $\mathrm{Li}_{2} \mathrm{MnSiO}_{4} / \mathrm{C}$ (sample C) is too low to be discussed. It is undoubted that small and uniform particle size brings considerable benefit to the rapid and reversible lithium extraction/insertion process, hence $\mathrm{Li}_{2} \mathrm{MnSiO}_{4} / \mathrm{C}$ (sample B) exhibits the lowest irreversible capacity and the best cyclic performance. However, compared with the commercial cathode materials such as $\mathrm{LiCoO}_{2}$, the capacity retention of $\mathrm{Li}_{2} \mathrm{MnSiO}_{4} / \mathrm{C}$ sample is still lower, which is associated with the $\mathrm{Mn}^{2+}$ dissolved and the Jahn-Teller distortion of $\mathrm{Mn}^{3+} .22-24$ The dissolution of $\mathrm{Mn}^{2+}$ decreases the amount of active materials involved in reaction, thus the low capacity is obtained. While the distortion also leads to the structural transformation from crystalline state to amorphous state during the charge-discharge process, but the exact mechanism of this process is still uncertain and needs to be further studied.

The effects of calcination temperature on the rate performance of $\mathrm{Li}_{2} \mathrm{MnSiO}_{4} / \mathrm{C}$ samples are exhibited in Fig.6. It indicates that the discharge capacities of all the samples decrease rapidly with increasing the current densities. Among these samples, $\mathrm{Li}_{2} \mathrm{MnSiO}_{4} / \mathrm{C}$ (sample A) has the highest capacity loss,
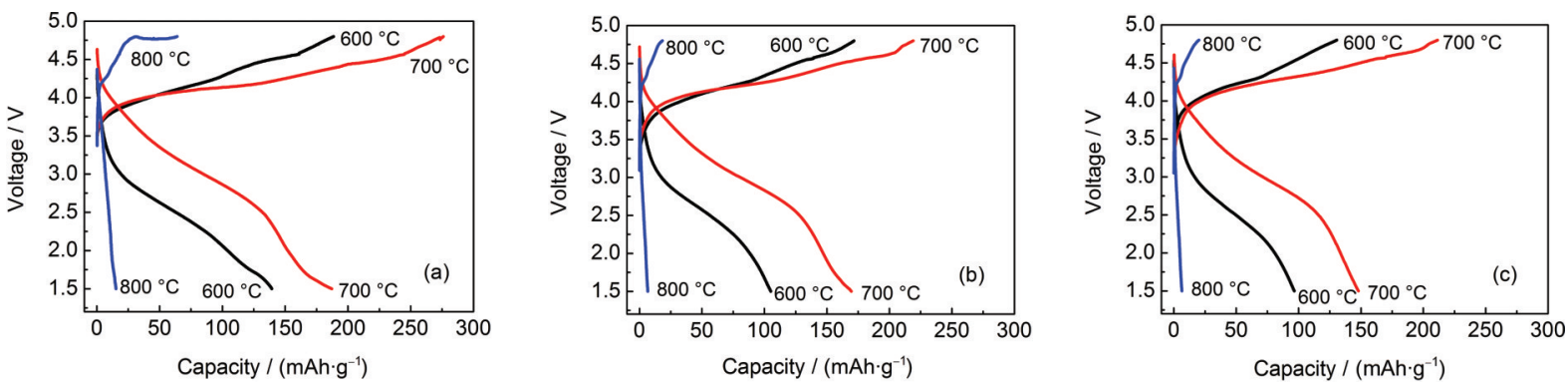

Fig.4 The initial charge-discharge curves of $\mathrm{Li}_{2} \mathrm{MnSiO}_{4} / \mathrm{C}$ samples prepared under different temperatures at various current densities (a) $5 \mathrm{~mA} \cdot \mathrm{g}^{-1}$, (b) $10 \mathrm{~mA} \cdot \mathrm{g}^{-1}$, (c) $20 \mathrm{~mA} \cdot \mathrm{g}^{-1}$
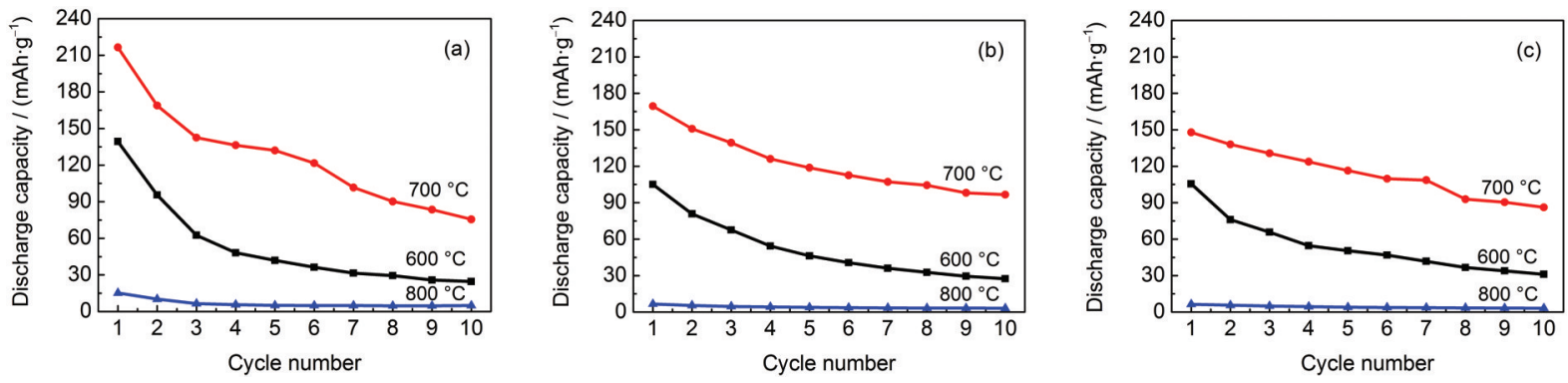

Fig.5 Cyclic performance of $\mathrm{Li}_{2} \mathrm{MnSiO}_{4} / \mathrm{C}$ samples prepared under different temperatures at various current densities

(a) $5 \mathrm{~mA} \cdot \mathrm{g}^{-1}$, (b) $10 \mathrm{~mA} \cdot \mathrm{g}^{-1}$, (c) $20 \mathrm{~mA} \cdot \mathrm{g}^{-1}$ 


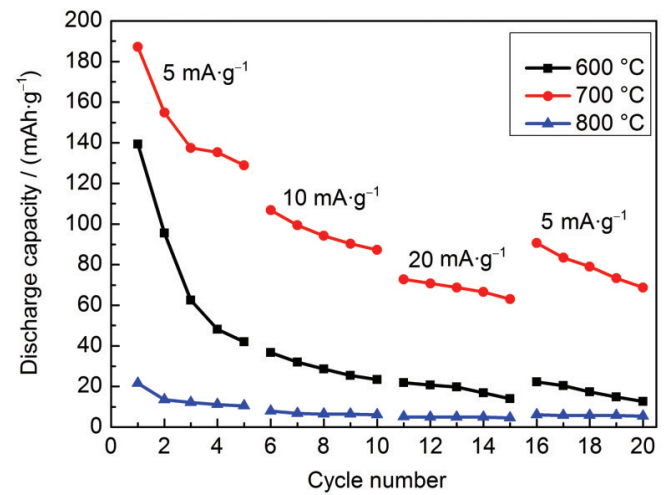

Fig.6 Rate performance of $\mathrm{Li}_{2} \mathrm{MnSiO}_{4} / \mathrm{C}$ samples prepared under different temperatures

from $139.31 \mathrm{mAh} \cdot \mathrm{g}^{-1}$ at $5 \mathrm{~mA} \cdot \mathrm{g}^{-1}$ to $36.67 \mathrm{mAh} \cdot \mathrm{g}^{-1}$ at 10 $\mathrm{mA} \cdot \mathrm{g}^{-1}$ and then $21.86 \mathrm{mAh} \cdot \mathrm{g}^{-1}$ at $20 \mathrm{~mA} \cdot \mathrm{g}^{-1}$. When the current density recovers to $5 \mathrm{~mA} \cdot \mathrm{g}^{-1}$, the discharge capacity only reaches $22.29 \mathrm{mAh} \cdot \mathrm{g}^{-1}$. In contrast, more stable cyclic performance at each current density and quite better reversible capacity are obtained for $\mathrm{Li}_{2} \mathrm{MnSiO}_{4} / \mathrm{C}$ (sample $\mathrm{B}$ ), which can be attributed to the superiority of structure and morphology to others. Small and uniform particle size of $\mathrm{Li}_{2} \mathrm{MnSiO}_{4} / \mathrm{C}$ (sample B) shortens the diffusion distance of lithium ion, and consequently the high capacity is obtained, especially at high current
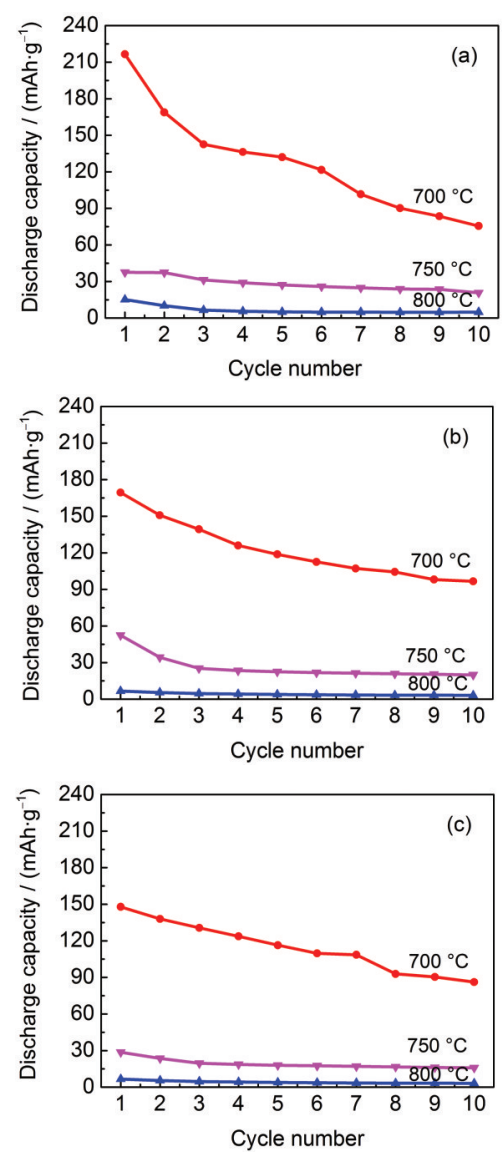

Fig.7 Cyclic performance of $\mathrm{Li}_{2} \mathrm{MnSiO}_{4} / \mathrm{C}$ (samples $\mathrm{B}, \mathrm{C}$, and D) at various current densities (a) $5 \mathrm{~mA} \cdot \mathrm{g}^{-1}$, (b) $10 \mathrm{~mA} \cdot \mathrm{g}^{-1}$, (c) $20 \mathrm{~mA} \cdot \mathrm{g}^{-1}$ density. However, the discharge capacity cannot recover at 5 $\mathrm{mA} \cdot \mathrm{g}^{-1}$ in the last 5 cycles, since the structure of $\mathrm{Li}_{2} \mathrm{MnSiO}_{4} / \mathrm{C}$ material changes into amorphous state, which is consistent with the other reports. ${ }^{15,25,26}$ Therefore, it is the important challenge to stabilize the structure of the sample.

As the large capacity difference exists between $\mathrm{Li}_{2} \mathrm{MnSiO}_{4} / \mathrm{C}$ (sample B) and $\mathrm{Li}_{2} \mathrm{MnSiO}_{4} / \mathrm{C}$ (sample C), the $\mathrm{Li}_{2} \mathrm{MnSiO}_{4} / \mathrm{C}$ (sample D) prepared at $750{ }^{\circ} \mathrm{C}$ is required to study the capacity change about the temperature range of $700-800{ }^{\circ} \mathrm{C}$. Fig. 7 shows the cyclic performance of $\mathrm{Li}_{2} \mathrm{MnSiO}_{4} / \mathrm{C}$ (sample $\mathrm{B}$ ), (sample C), and (sample D) at 5,10 , and $20 \mathrm{~mA} \cdot \mathrm{g}^{-1}$. For the $\mathrm{Li}_{2} \mathrm{MnSiO}_{4} / \mathrm{C}$ (sample D), the discharge capacity is a little higher than $\mathrm{Li}_{2} \mathrm{MnSiO}_{4} / \mathrm{C}$ (sample $\mathrm{C}$ ), but much lower than $\mathrm{Li}_{2} \mathrm{MnSiO}_{4} / \mathrm{C}$ (sample $\mathrm{B}$ ). It means that the electrochemical performance of $\mathrm{Li}_{2} \mathrm{MnSiO}_{4} / \mathrm{C}$ composite is extremely sensitive to the calcination temperature. And it is confirmed that $700{ }^{\circ} \mathrm{C}$ is the optimal temperature.

\section{Conclusions}

$\mathrm{Li}_{2} \mathrm{MnSiO}_{4} / \mathrm{C}$ cathode materials have been successfully synthesized under different calcination temperatures via a solution route. XRD patterns indicate that all samples have an orthorhombic structure with the space group $P m n 2_{1}$. However, the sample prepared at $700{ }^{\circ} \mathrm{C}$ shows much better electrochemical performance than the others, the initial discharge capacity reaches $187.12 \mathrm{~mA} \cdot \mathrm{g}^{-1}$ at $5 \mathrm{~mA} \cdot \mathrm{g}^{-1}$ rate and about $100 \mathrm{mAh}$. $\mathrm{g}^{-1}$ capacity retention at the 10 th cycle. That is because lower level impurities, more uniform, and smaller particle size are exhibited for the optimal sample.

\section{References}

(1) Padhi, A. K.; Nanjundaswamy, K. S.; Goodenough, J. B. J. Electrochem. Soc. 1997, 144, 1188.

(2) Padhi, A. K.; Nanjundaswamy, K. S.; Goodenough, J. B. J. Electrochem. Soc. 1997, 144, 1609.

(3) Padhi, A. K.; Nanjundaswamy, K. S.; Masquelier, C.; Goodenough, J. B. J. Electrochem. Soc. 1997, 144, 2581.

(4) Arroyo-de Dompablo, M. E.; Armand, M.; Tarascon, J. M.; Amador, U. Electrochem. Commun. 2006, 8, 1292.

(5) Zhou, F.; Cococcioni, M.; Kang, K.; Ceder, G. Electrochem. Commun. 2004, 6, 1144.

(6) Nytén, A.; Abouimrane, A.; Armand, M. Electrochem. Commun. 2005, 7, 156.

(7) Nytén, A.; Kamali, S.; Haggstrom, L.; Gustafsson, T.; Thomas, J. O. J. Mater. Chem. 2006, 16, 2266.

(8) Islam, M. S; Dominko, R.; Masquelier, C.; Sirisopanaporn, C.; Armstrong, A. R.; Bruce, P. G. J. Mater. Chem. 2011, 21, 9811.

(9) Zaghib, K.; Ait Salah, A.; Ravet, N.; Maguger, A.; Gendron, F.; Julien, C. M. J. Power Sources 2006, 160, 1381.

(10) Dominko, R.; Conte, D. E.; Hanzel, D.; Gaberscek, M.; Jamnik, J. J. Power Sources 2008, 178, 842.

(11) Yang, Y.; Fang, H. S.; L, L. P.; Yan, G. F.; Li, G. S. Rare Metals 
and Engineering 2008, 6, 1085.

(12) Belharouak, I.; Abouimrane, A.; Amine, K. J. Phys. Chem. C 2009, 113, 20733.

(13) Liu, W. G.; Xu, Y. H.; Yang, R. J. Alloy. Compd. 2009, 480, L1.

(14) Dominko, R.; Bele, M.; Gaberscek, M.; Meden, A.; Remskar, M. J. Electrochem. Commun. 2006, 8, 217.

(15) Dominko, R.; Bele, M.; Kokalj, A.; Gaberscek, M.; Jamnik, J. J. Power Sources 2007, 174, 457.

(16) Dominko, R. J. Power Sources 2008, 184, 462.

(17) Aravindan, V.; Ravi, S.; Kim, W. S.; Lee, S. Y.; Lee, Y. S. J. Colloid Interface Sci. 2011, 355, 472.

(18) Liu, W. G.; Xu, Y. H.; Yang, R. Rare Metals 2010, 29, 511.

(19) Guo, H. J.; Xiang, K. X.; Cao, X.; Li, X. H.; Wang, Z. X.; Li, L. M. Trans. Nonferrous Met. Soc. China 2009, 19, 169.
(20) Kam, K. C.; Gustafsson, T.; Thomas, J. O. Solid State Ionics 2011, 192, 356.

(21) Li, L. M.; Guo, H. J.; Li, X. H.; Wang, Z. X.; Peng, W. J.; Xiang, K. X.; Cao, X. J. Power Sources 2009, 189, 45.

(22) Ohzuku, T.; Kitagawa, M.; Hirai, T. J. Electrochem. Soc. 1990, 137,769 .

(23) Jang, D. H.; Shin, Y. J.; Oh, S. M. J. Electrochem. Soc. 1996, 143, 2204.

(24) Muraliganth, T.; Stroukoff, K. R.; Manthiram, A. Chem. Mater. 2010, 22, 5754 .

(25) Li, Y. X.; Gong, Z. L.; Yang, Y. J. Power Sources 2007, 174, 528.

(26) Kokalj, A.; Dominko, R.; Mali, G.; Meden, A.; Gaberscek, M.; Jamnik, J. Chem. Mater. 2007, 19, 3633. 